\title{
The Concept of E conomic Operator and the Setting of Limitations to Awarding by Lots in Public Procurement in the Light of the Portuguese Public Contracts Code
}

\author{
Nuno Cunha Rodrigues
}

\begin{abstract}
:
According to theEU 2014 directives, the contracting authority should divide intolots - or to justify not doing so. Furthermore, it may decide (i) to limit the number of lots to which each economic operator may submit tenders; (ii) tolimit the maximum number of lots to beawarded per economic operator, or (iii) to aggregate all or part of the lots.

In view of the limitation on the number of lots for which tenders may be submitted or the maximum number of lots to be awarded per competitor - either limitation to be determined in advance at the contracting authority's discretion - the article addresses the question of whether al beit legally distinct competitors that maintain an economic unit or interdependent links may submit bids for different lots or groups of lots in the same procedure.
\end{abstract}

Keywords:_lotting; competition; Portuguese Public Contracts Code; Concept of undertaking; economic operator.

\section{Awarding by lots and the promotion of SME participation in public procurement}

The new 2014 package of directives on public procurement was negotiated during the economic crisis that has affected parts of the European Union since 2008. It sought to take advantage of the economic impact generated by public procurement - equivalent, on average, to some $16 \%$ of the GDP of each EU Member State. ${ }^{1}$ The policy aims were to link public procurement more clearly with the pursuit of so-called horizontal or secondary policies, with ulterior goals traditionally less connected to the objectives of public procurement such as environmental protection or promoting of social policies. ${ }^{2}$

Among other policies, it was sought to promote the participation of small and medium-sized enterprises (SMEs) in pre-contractual procedures. Studies then conducted by the European Commission had shown that these companies were frequently rejected in public procurement procedures for a variety of reasons, including bureaucratic obstacles, or resulting from the generally lower economic efficiency of SMEs when compared with large corporations. ${ }^{3}$

\footnotetext{
${ }^{1}$ See European Commission data for the year 2016 available at http://eceuropa.eu/trade/policy/accessingmarkets/public_procurement/

About promoting the participation of SMEs in public procurement, v. ANTHONY FLYNN, Investigating the implementation of SME_friendly policy in public procurement, Policy Studies, 39:4, 2018, pp. 422-443.

2 Regarding these policies, see NUNO CUNHA RODRI GUES, A contratação pública como instrumento de política económica, Almedina, Coimbra, 2013, reimpressão, pp. 260-303.

${ }^{3}$ In this regard, seethe report of the E uropean Commission Evaluation of SMEs' access to public procurement markets in the EU - Final Report, Ares (2014)75984 - 15/01/2014, available at
} 
It is accordingly understandable that the 2014 directives have regulated instruments such as the European Single Procurement Document ${ }^{4}$; enhanced electronic public procurement ${ }^{5}$ and defined the rule of awarding by lots (linked to the 'divide or explain' principle) ${ }^{6}$, with the intention of increasing SME participation and thereby fostering competition in public procurement. ${ }^{7}$

This fresh perspective on public procurement led some scholars to refer to a paradigm shift, from an approach followed until 2014 which centered on an aggregating dimension of public procurement by prohibiting the splitting/reduction of expenditure ${ }^{8}$, to an approach from 2014 onwards which also contemplated a disaggregating (or splitting) dimension of public procurement. $^{9}$

One of the most significant innovations introduced in the revision of the Portuguese Public Contracts Code (PPCC), approved in 2017 by the Decree Law no. $111-B / 2017$, of 31 August 31, concerns the obligation for contracting authorities covered by the Classical Directive to proceed as a rule to the award of public contracts by lots. This obligation applied to public contracts for the purchase or hire of goods or services valued over EUR 135,000.- and public works contracts of a

http://eceuropa.eu/DocsRoom/documents/2153/attachments/1/ translations/en/renditions/pdf, in particular pp. 110-114.

4 See Artide 59 of Directive 2014/24 / EU (henceforth referred to as theClassical Directive).

5 See Directive 2014/55 / EU of the European Parliament and of the Council of 16 April 2014 on electronic billing for public contracts.

${ }^{6}$ See Artide 46 of the Classical Directive.

7 See recital 78 to the Classical Directive, stating that "... in order to increase competition, contracting authorities should be encouraged in particular to divide large contracts intolots."

Until 2014 the European directives did not regulate the division of batch contracts or theaggregation of those lots.

The reference to the division of bundled or aggregated contracts was provided in the notice that, where the contracts weresubdivided into lots, the contracting authority should indicate the possibility of bidding for one, for several or for all lots (see annex VII a to Directive 2004/18).

8 Se LUÍS VERDE DE SOUSA, Algumas notas sobre a adjudicação por lotes, in Revista E-pública, vol ume 4, no 2, November 2017, avai lableat http://e-publica.pt/volumes/v4n2a04.html, p. 69 adding, ibidem, p. 71, that the unbundling or division into lots does not necessarily entail a batch award since the contracting authority may use more than one procedure to award the parts in which it has decided to split the unit (provided that the subject matter of the contract is divisible).

The award by lots should also not be confused with the prohibition of splitting the expenditure, according to which the contract, depending on the contractual value, cannot be divided into several procedures if the subject matter can be awarded in the same procedure.

This prohi bition is provided for in Artidell (7) of the Government Procurement Agreement (GPA) bytheWorld Trade Organization; in Artide 5(2) of the Classical Directive and in Articles 17(8) and 22(1) of the Portuguese Public Contracts Code (PPCC).

${ }^{9}$ Se LUÍS VERDE DE SOUSA, Algumas notas..., p. 70. 
value greater than EUR 500,000... Contracting authorities may refrain from such splitting, however, provided the decision is duly justified (see Article 46-A(1) of the PPCC). ${ }^{10}$

The principle of "divideor explain" was thus enshrined, which constitutes a pressing obligation on the contracting authority to divide lots "in the absence of sufficient reason to decide otherwise".11

\section{Awarding by lots:}

\subsection{Discretion of the contracting authority and the "divide or explain" obligation:}

In awarding by lots, the object subject to competitive tendering must be divided in such a way as to enable each of the resulting segments (or the whole, as explained below) to be awarded independently, even in the same procedure (see Article 46-A(1) of the PPCC).

Without prejudice to its obligation to effect a division into lots - or to justify not doing so - the contracting authority may decide in advance in the call or in the program of the procedure (i) to limit the number of lots to which each economic operator may submit tenders; (ii) to limit the maximum number of lots to be awarded per competitor, or (iii) to aggregate all or part of the lots (lot bundling). This possibility results from Article 46-A of the PPCC, which provides that in the parts of the procedure the contracting authority may:

a) limit the maximum number of lots that can be awarded to each competitor (restriction on arrival ${ }^{12}$ ) and must indicate these limitations in the call or the program of the procedure along with the objectiveand non-discriminatory criteria on which the choice of lots to beawarded to each

${ }^{10}$ The Classical Directive confers on Member States the freedom to determinewhether the division into lots is mandatory.

Seerecital 78 of the Classical Directive: "Member States should befreeto go further in their efforts tofacilitate the participation of SMEs in the public procurement market by extending the scope of the obligation to consider whether todivide contracts intosmaller lots, requi ring contracting authorities to justify thei $r$ decision not to di vide the contracts into lots or to make the division into lots compulsory under certain conditions. To the same effect, Member States should also be free to provide for direct payment mechanisms to subcontractors."

In the special sectoral directive (Directive 2014/25/EU), a more flexible regime was established. In that case, the duty to state the reasons why a contract was not divided appears in recital 87 as a mere possibility for Member States to go beyond the directives and in Article 65 (1), which contains the rule allowing awarding by lots. Lastly, the Concessions Directive (2014/23/EU) does not expressly refer to awarding by lots. In this regard, see MIGUEL ASSIS RAIMUNDO, Dever de ponderação da adjudicação por lotes e dever de fundamentação da não divisão no direito dos contratos públicos, in Revista E-pública, vol. 4, n.ำ2, November 2017, p. 27.

${ }^{11}$ Se MI GUEL ASSIS RAI MUNDO, Dever de ponderação ..., p. 24.

The PPCC presents the following exemplary list of grounds for non-division: (a) where the services to be covered by the respective object are technically or functionally inseparable, or if their separation would cause serious inconvenience to the contracting authority; (b) where, for reasons of urgency or for technical or functional reasons, the management of a single contract is more efficient for the contracting authority.

${ }^{12}$ Se LUÍS VERDE DE SOUSA, Algumas notas ... p. 73. 
tenderer is based in cases where the application of the award criteria results in the allocation to the same tenderer of more than the maximum fixed number (seeno. .4 ), and

b) conclude contracts combining several or all lots, provided that such a possibility is expressly mentioned in the invitation or the program of the procedure, in which case the criteria underlying the various combination scenarios provided for must beestablished and indicated in advance (see no.우);

The contracting authority also has the power to set limits in advance on the number of lots for which an applicant may apply (restriction at departure) which, although not explicitly contained in Article 46-A of the PPCC, is accepted in recital 79 of the Classical Directive, as a way of "preserving competition or ensuring reliability of supply". ${ }^{13}$

In other words, the contracting authority may decide in advance, in the call or in the program of the procedure: (i) to limit thenumber of lots to which each economic operator may submit tenders; (ii) to limit the maximum number of lots to be awarded to a single competitor, or (iii) to aggregate part or all of the lots (lot bundling) ${ }^{14}$ to be awarded without having to formally justify any of the options taken. Instead the contracting authority must only establish, in the invitation or in the procedure: (a) the objective and non-discriminatory criteria which determine the choice of lots to be awarded when the maximum number of lots is exceeded ${ }^{15}$, or (b) the criteria underlying the possibilities of planned aggregated lots. ${ }^{16}$

${ }^{13}$ Assuming this possibility, see J OSÉ DU ARTE COI MBRA, A adjudicação..., pp. 366-367 and LUÍS VERDE DE SOUSA, Algumas notas ..., pp. 73 and 75

${ }^{14}$ On the awarding of aggregated lots, see LUÍS VERDE DE SOUSA, Algumas notas ..., pp. 80-84 and LAURA CARPINETI, GUSTAVO PIGA and MATTEO ZANZA, Benchmarking European Public Procurement Practices: Purchasing of 'Fix-Line Telephone Services' and 'Paper for Printers' (September 2006), available SSRN: https://ssrn.com/abstract $=934504$ who report a case in I taly where the national central purchasing body (Consip) decided in J uly 2002 to approve a procedure for the award of two lots: one for landline telecommunications services and the other for mobile telecommunications services. It was also possiblefor competitors to submit aggregated tenders for the two lots, which did not prevent the two lots from being ultimately awarded to two different competitors.

15 SœJ OSÉ DUARTE COIMBRA, A adjudicação..., p. 366.

${ }^{16}$ As observed by LUÍS VERDE DE SOUSA, Algumas notas ..., p. 83, in a scenario of aggregated awarding, "in addition to the award criterion and the tie-breaking criterion (see Artide 74(4) of the PPCC), the contracting authority must also indicate the criterion (or criteria) for theawarding of aggregated lots" which is "subject to a single quantitative limit, corresponding to the verification that the whole (i.e the aggregation of lots) is better (because the price is lower or the score is higher) than the sum of the different parts, all while excluding the need of proving that this asset is substantial or significant." (ibidem, p. 81).

A related issue is whether the submission of conditional tenders is permissible, i.e whether tenderers can submit variable tenders depending on the number and types of lots to be awarded to them. 
Some scholars see the rule of awarding by lots as a mechanism to counteract, if only impliedly, the modern trend of centralization of public procurement that accompanies economies of scaleand the concentration of market power (buyer power) conferred on public entities. ${ }^{17}$

The increased purchasing power of public entities (buyer power) may result in some cases in an effective monopsony, which in turn could distort the competitive functioning of the markets by leading to the removal of SMEs from purchasing centres. ${ }^{18}$

From this perspective, the $\mathbf{2 0 1 4}$ directives are somewhat paradoxical in that they aim on the one hand to promote SME participation in public procurement ${ }^{19}$, but on the other hand to facilitate the centralization of public procurement, which itself may lead to a distancing of SMEs from these centres, given the smaller economies of scale they are able to generate when compared to large companies. However this would be a precipitate conclusion, since the objectives of centralizing purchasing and division into lots are different, and because purchasing centres are also subject to the divide or explain principle.20

The awarding by lots rule (divide or explain) may thus legitimately be seen as one of the most significant instruments to ensure increased SME participation in pre-contractual procedures. However, the promotion of SME participation in public procurement is not equivalent to giving a

17 Concerning the centralization of public purchases, se ALBERT SANCHEZ-GRAELLS and IGNACIO HERRERA ANCHUSTEGUI, I mpact of Public Procurement Aggregation on Competition: Risks, Rationale and J ustification for the Rules in Directive 2014/24 (December 5, 2014). University of Leicester School of Law Research Paper n.o 14-35, available at SSRN: https://ssrn.com/abstract=2534496; IGNACIO HERRERA ANCHUSTEGUI, Centralizing PublicProcurement and Competitiveness in Directive 2014/24 (J uly 20, 2015), available at SSRN: https://ssrn.com/abstract=2633445 and MARCO CALDEIRA, A centralização das compras públicas: a propósito (mas não só...) das Directivas de 2014, in Revista de Contratos Públicos, CEDIPRE, n.14 (May-August 2014), pp. 19-44.

The 2014 directives extended the possibility of centralizing public procurement by making it possible, for example, to create cross-border contracting authorities. Nonetheless, the centralization of public procurement has been closely monitored by the European Commission and several competition authorities (National Competition Authorities - NCA) all across the European Union. See recital 59 of the Classical Directive. "the aggregation and centralisation of purchases should be carefully monitored in order to avoid excessive concentration of purchasing power and collusion, and to preserve transparency and competition, as well as market access opportunities for SMEs."

${ }^{18}$ In an economic and competitive law analysis of purchasing power (including public procurement), see CAROLINA SAITO and ZACK DOUER, Grupos de compras: cooperação ou colusão?, in Revista de Direito da Concorrência, CADE, n. ${ }^{\circ}$ 1, volume 6, May 2018, pp. 120-155.

19 With data concerning the difference between the share of SME's in public procurement and their role in the economy, see GUSTAVO PIGA, Centralization vs. bundling: the victory of an Italian David against an Italian Goliath, in European Journal of Public Procurement Markets, 1st issue, October 2018, pp. 70-71.

${ }^{20}$ See MIGUEL ASSIS RAIMUNDO, Dever de ponderação ..., p. 32. This duty must be fulfilled in any pre-contractual procedure, in particular in the framework agreements often used by central purchasing bodies.

As GUSTAVO PIGA recognizes in Centralization vs. bundling: the victory of an Italian David against an Italian Goliath, European Journal of Public Procurement Markets, 1st issue, October 2018, p. 68, "centralization does not need to be inevitably tied to the aggregation of tenders in ever bigger lots". 
guarantee of the award of lots to SMEs. It may even be the case that the contracting authority (i) opts not to divide into lots for any reason duly substantiated (see above), or (ii) despite a division into lots, makes no award to SMEs. ${ }^{21}$

The legal procedure provided for by the Portuguese legislator grants the contracting authority a margin of discretion in the definition and implementation of lot-splitting, even though this is confined to the configuration of lots in qualitative and quantitative terms. ${ }^{22}$

In this context, the contracting authority must duly substantiate compliance with the "divide or explain" obligation, it being understood that this weighting, when carried out in an appropriate manner, will hinder a possible judicial scrutiny. ${ }^{23}$

For this reason, the contracting authority must first consider the exceptional situation ${ }^{24}$ in which it opts not to divide into lots.

${ }^{21}$ It should be noted in this regard that it is somewhat incomprehensiblefor the PPCC to determinein Article 74(6) of the PPCC that, in the event of a tie between tenders, preference should be given to that presented by an SME, in that such a choice by the national legislator is not stated (nor could it be) in the 2014 directives and, on the other hand, it violates the equality principle laid down in Artide 13 of the Constitution of the Portuguese Republic.

22 See recital 78 of the Classical Directive. "The size and subject-matter of the lots should be determined freely by the contracting authority (...)".

Regarding procedural discretion in division into lots, see J OSÉ DUARTE COIMBRA, A adjudicação..., pp. 328-346

23 See recital 78 of the Classical Directive. "Where the contracting authority decides that it would not be appropriateto dividethecontract intolots, the individual report or the procurement documents should contain an indication of the main reasons for the contracting authority's choice"

The present author shares, however, the understanding of MIGUEL ASSIS RAIMUNDO, Dever de..., p. 39 for whom the decision of the contracting authority is legally open to scrutiny in the light of the general principles of public procurement and in particular of the principle of competition, for which reason the reasoning relied on by the contracting authority not to be divided into lots must appear in the underlying administrative file in the pre-contractual procedure concerned.

${ }^{24}$ The exceptional nature is inferred from the wording, even if exemplary, provided for in Artide 46 -A, no 2, which refers to the exemplary cases where (a) the benefits are technically or functionally unavailable or, (b) where, for reasons of urgency or for technical or functional reasons, the management of a single contract proves to be more efficient for the contracting authority.

See recital 78 of the Classical Directive: “...the contracting authority finds that such division could risk restricting competition, or risk rendering the execution of the contract excessively technically difficult or expensive, or that the need to coordinatethe different contractors for the lots could seriously risk undermining the proper execution of the contract." 


\subsection{Impact on competition of division into lots (lotting)}

As GIAN LUIGI ALBANO observes, the decision to divide a contract into lots is one of the most significant in the design of a competitive pre-contractual procedure ${ }^{25}$ Thus, theanticipation of the market response to the division into lots underlying the pre-contractual procedure may even in some cases entail the need for preliminary market research (see Article 35-A of the PPCC), since the division into lots should be oriented towards the upholding of competition. ${ }^{26}$ The contracting authority may consider several criteria for dividing into lots, including (i) geographical; (ii) divisibility of the product; (iii) the price of the various lots; (iv) the operational division of the service, or (v) others.27

Either option will have both advantages and disadvantages, which must be duly anticipated and weighed by the contracting authority.

For instance, deciding to divide into lots based on geographical criteria may facilitate the geographical distribution of markets but also creates incentives for collusion between competitors. ${ }^{28}$ Division into lots based on consistent and constant base prices has commercial advantages but may al so facilitate collusion between competitors.

${ }^{25}$ Se GIAN LUIGI ALBANO, Working Party no. .2 on Competition and Regulation -Competition in Public Procurement Markets, 19J une 2017, available

https://one.oecd.org/document/DAF/COMP/WP2(2017)1/en/pdf , p. 10: "By affecting the number and the type of firms that are able to compete, 'lots design' can have a dramatic impact on the intensity of competition in the market, and hencefor current and potential future contracts."

26 In this regard, se NUNO CUNHA RODRIGUES, O princípio da concorrência nas novas diretivas sobre contratação pública, in Maria J oão Estorninho (coord.), A Transposição das Diretivas Europeias de 2014 e o Código dos Contratos Públicos, ICJ P / CIDP, 2016, available at https://www.icjp.pt/publicacoes/pub/1/9030/view and MIGUEL ASSIS RAIMUNDO, Aiming themarket you want: a critical analysis of theduties on division into lots under Directive 2014/24/EU, in P.P.L.R. 2018, 4, pp. 167-187 (in particular pp. 178.179).

${ }^{27}$ Concerning the division criteria, see recital 78 of the Classical Directive. "Such division could be done on a quantitative basis, making the size of the individual contracts better correspond to the capacity of SMEs, or on a qualitative basis, in accordance with the different trades and specialisations involved, to adapt the content of the individual contracts more dosely to the specialised sectors of SMEs or in accordance with different subsequent project phases."

${ }^{28}$ Herecomes into question an agreement between companies which infringes Article 101, no1 TFEU or Article 9, no 1 of the Competition Law.

In this regard, se v. Ski Taxi, Case E-03/16, decided by the EFTA Court, on December 22 2016, availableat http://www.eftacourt.int/cases/detail/?tx_nvcases_pi1\%5Bcase_id\%5D=281\&cHash=77ab5837d77b1e3b57be524fc45a0394 in which a cartel was set up following the launch by the Oslo Hospital in 2010 of a call for tenders for the conclusion of framework agreements on the transport of patients, which was divided into nine lots organized by geographical areas adjacent to the Hospital. For two of these lots, the Hospital received only one proposal, presented jointly by twotaxi companies. Sincethecontracting entity - the Hospital _ expected different tenders to be submitted, it was understood that there was a cartel and therefore the procedure for these two lots was cancelled and the Norwegian Competition Authority prosecuted the two companies, potentially competitors, on the grounds that there was a cartel (object restriction). Later the lots were redesigned which allowed the emergence of new competitors. 
Seen in this light, the option to award by lots is a complex undertaking. ${ }^{29}{ }_{-} 30$

Nevertheless, splitting generally generates efficiency gains which accrue to the contracting authority, ensuring in particular:

a) the sharing of risks that the award of various lots generates between different suppliers, thus avoiding excessive dependence or concentration of the contracting authority on a single or a few suppliers;

b) the possibility of allowing competitors at a regional or local level to submit proposals which they would otherwise be unable to do (e.g. in the case of lots with a national dimension);

c) an increase of suppliers, thus al lowing the contracting authority to compare the performance of different contracts by different suppliers;

d) an increase in market dynamism, based on varied approaches and solutions inherent in each lot, given the possibility of several competitors to simultaneously ensure the supply of goods and services;

e) the possibility of new entrants to the markets (e.g. SMEs and specialized companies), in particular where the division contemplates lots of heterogeneous goods or services ${ }^{31}$;

In this regard, see NUNO CUNHA RODRIGUES, Contratação Pública e concorrência: de mãos dadas ou de costas voltadas?, in Revista de Concorrência \& Regulação, ano VIII, n. 32, October-December 2017, pp. 131. 145.

Believing that the division of contracts into geographical lots could allow greater participation of SMEs which, for logistical reasons, would be unable to compete, se GIAN LUIGI ALBANO, Working Party No. 2 on Competition and Regulation -Competition in Public Procurement Markets, 19 J une 2017, disponível em https://one.oecd.org/document/DAF/COMP/WP2(2017)1/en/pdf , p. 12.

${ }^{29}$ Criticizing the preference for the award by lots, see MIGUEL ASSIS RAI MUNDO, Dever de ponderação ..., p. 27.

Regarding the advantages and disadvantages of division into lots, see al so ALBERT SANCHEZ GRAELLS, Public Procurement and the EU Competition Rules, 2. ${ }^{\text {a }}$ edição, Oxford Hart, 2015, pp. $347-352$ and ALBERT SANCHEZ-GRAELLS, Prevention and Deterrence of Bid Rigging: A Look from the New EU Directive on Public Procurement (April 1, 2014), published in G Racca \& C Yukins (eds), Integrity and Efficiency in Sustainable Public Contracts (Brussels, Bruylant, 2014), available at SSRN: https://ssrn.com/abstract=2053414. In American doctrine, see D. PANGBURN, The Impact of Contract Bundling and Variable-Quantity Contracts on Competition and Small Business, in Public Contract L aw J ournal, 1995-1996, p. 69 el. AKYUZ, Bundling into the Millenium: Analyzing the Current State of Contract Bundling, Public Contract Law J ournal, 2000-2001, p. 123.

${ }^{30}$ SeeGIANCARLO SPAGNOLO and CHRISTOPHER R. YUKINS, Lots - theeconomic and legal challenges of centralized procurement, in Gustavo Piga / Tunde Tatrai (eds.), Public Procurement Policy, Routledge, 2016 and GUSTAVO PI GA, Central ization vs. bundling: the vidory of an Italian David against an I talian Goliath, in European J ournal of Public Procurement Markets, 1st issue, October 2018, pp. 67-78.

${ }^{31}$ What may occur with, eg., computer software, chemical reagents or medical equipment. 
f) a reduction of the lock-in ${ }^{32}$ effect that can be verified by two essential factors:

i) the learning curve (learn by doing) that the incumbent company benefits from as it reflects on the proposal in thelight of acquired experience. Thesupplier's knowledge of theneeds of the contracting authority strengthens its ability to present better proposals in subsequent procedures which, in monopsony situations ${ }^{33}$, may prevent other tenderers from submitting proposals and therefore benefiting from the learning curve.

ii) reduced costs. The need to make investments which are not recoverable (eg. in infrastructure) may alienate other competitors, thus creating a barrier to entry.

g) reduced risk of explicit collusion in so far as the possibility for different types of companies to submit proposals in the same procedure (e.g SMEs and large companies) will mitigate possible collusivestrategies that may arise between similar companies often present in cartels. It may even be said that the greater the number of potential companies competing, the less potential for collusion between them. ${ }^{34}$

On the other hand, the division into lots can havenegative impacts as follows:

a) it potentially reduces competition, in particular by removing large companies for which small lot procedures may be unattractive. ${ }^{35}$ This ultimately depends on the relationship between the numbers of lots and potential interested parties, which is why this argument can be considered reversible.

b) the cost of the good or service to be provided to the contracting authority (value for money) may be higher in view of the potential reduction of economies of scale resulting for bidders arising out of the division of lots;

${ }^{32}$ Concerning the lock-in effect in public procurement, se NUNO CUNHA RODRIGUES, A contratação pública ..., p. 90.

33 Regarding the power of monopsony in public procurement, see NUNO CUNHA RODRIGUES, A contratação pública ..., p. 90.

${ }^{34}$ In this regard, see R. P. MCAFEE and J . MCMILLAN, Incentives in Government Contracting, pp. 57-60; V. GRIMM et alli, Division into Lots and Competition in Procurement, in N. Dimitri et al (eds. by), Handbook of Procurement, Cambridge, Cambridge University Press, 2006, pp. 168 and 175. 54 and L. CARPINETI et alli, TheVariety of Procurement Practice: Evidencefrom Public Procurement, in N. Dimitri et alli, Handbook of Procurement, Cambridge, CambridgeUniversity Press, 2006, pp. 14 and 23-24.

See also see GUSTAVO PIGA, Centralization vs. bundling: the victory of an Italian David against an Italian Goliath, in European J ournal of Public Procurement Markets, 1st issue, October 2018, pp. 74.75.

${ }^{35}$ See J .-Y. CHEROT, Droit public économique, Paris, Economica, $2^{\text {nd }}$ edition, 2007, p. 728. Against the aggregation of lots due to the anti-competitive effects it can generate, see also OFT, Assessing the I mpact of Public Sector Procurement on Competition, 2004, pp. $16-20$ e 110-125 and recital n.o 25/2012 - 24. jul. 1. $\mathrm{s} / \mathrm{SS}$ of the Court of Auditors, in which it was stated that a provision of a tendering program which limited the possibil ity of awarding to a single tenderer only two lots (in a universe of five), "is likely to have limited the universe of potential competitors, in that some potential interested parties would be interested only in submitting proposals if they could be awarded all lots, possibly aiming for economy of scale". 
c) awarding by lots may not be possible in the case of certain goods and services (e.g. public works contracts);

d) technical problems may arise during the execution of the contracts, taking into account the different approaches that each supplier will adopt in executing the lot awarded to them;

d) it cannot be assumed that the lots are necessarily awarded to different competitors. Although the division intolots promotes competition, it may ultimately bethat they areawarded tothesame competitor, thus prolonging the risk of lock_in;

e) it may lead to inefficiencies among competitors since, in the case of awarding by lots, largefirms that benefit from economies of scale, which cannot begenerated through small lots, may withdraw from the procedure or convert inefficiency into an increased cost of the proposal (see above item b));

f) it fadilitates collusion by solving issues inherent in theformation and distribution of lots between members of a cartel (eg. in the case of geographical division of lots or division of lots on the basis of the same price);

The disadvantages listed must be resolved or mitigated through the application of various solutions. ${ }^{36}$

In particular, in may be possible to determine, through prior procedural design, the award of combined or aggregated lots in addition to the award of individual lots (package bidding). ${ }^{37}$

It is also possible to define a maximum number of lots to be awarded per competitor, in which case competitors may be required to indicate the order of preference of lots for which they submit their tenders, in case the maximum number of lots to be awarded is exceeded.

These solutions will generate different strategic behaviours on the part of competitors, in particular because:

1) in fixing of a maximum number of lots to be awarded per tenderer, it is possible that:

a) the incentive towards collusion between competitors increases, since competitors can always justify the non-submission of tenders for certain lots with the fact that the maximum number of lots for which they can compete is limited, thereby making it difficult to detect bid-rigging ${ }^{38}$ practices;

b) the ability of competitors to submit tenders becomes limited. Thus, the division into two heterogeneous lots, one of high valueand another of residual value, may lead to largecompanies submitting proposals only for the larger lot, leaving to SMEs the submission of proposals for the lowest value lot(s), which, while promoting the participation of SMEs, ultimately leads to a

\footnotetext{
${ }^{36}$ Closely following some of the hypotheses suggested by GI AN LUIGI ALBANO, Working Party ..., p. 12.

${ }^{37}$ See redital 79 and Artide 46(3) of the Classical Directive Concerning package bidding, see N. DI MITRI , R. PACINI, M. PAGNOZZ , \& G. SPAGNOLO, MultiContract Tendering and Package Bidding in Procurement, in N. Dimitri, G. Piga, and G. Spagnolo(Eds.). Handbook of Procurement 2006, CambridgeU niversity Press, pp. 193-219.
}

${ }^{38}$ V. ALBERT SANCHEZ-GRAELLS, Prevention and Deterrence..., passim. 
reduction in competition in the procedure and leads the contracting entity to accept less competitive and less efficient proposals, resulting in turn in a loss of value for money.

On theother hand, it is legitimate to consider that this solution may have pro-competitive effects by allowing new competitors to enter the market.

Finally, in high value public contracts (e.g. framework agreements managed by centralized agencies ${ }^{39}$ ), it can be considered whether the value of the lots should be similar (homogeneous lots) or different (heterogeneous lots), anticipating the competitors' reaction to this division. In some cases, dividing into heterogeneous lots can also facilitate the task of distribution between (asymmetric) members of a cartel. In this case, the division into heterogeneous lots should seek to anticipate any correspondence with the market share of potential competitors and modify the division so as to avoid this correspondence in the lot division;

2) The risk of division into lots facilitating collusion can be mitigated by dividing the contract into fewer lots than the expected number of competitors. Given the impossibility of all competitors winning lots, the stability of the cartel will be disrupted, forcing an understanding of the specific lots concerned by the cartel, thereby increasing the likelihood of detection of anti-competitive practices in the procedure.

On the other hand, the number of lots to be awarded must exceed the number of incumbents, in order to facilitate the emergence of new entrants or competitors.

Finally, lots should not be stable and predictable. Contracting authorities should modify the batch division carried out in previous procedures, making it less predictable for potential competitors.

In consideration of the solutions described above, reflected in the procedural design prepared by the contracting authorities, competitors may submit tenders (i) for one of the lots; (ii) for a substantial portion of the lots, or (iii) for all lots. When tendering for a single lot, competitors must identify in the tender the lots they prefer, in ascending or descending order of preference.

With tenders for aggregated lots (or package bidding), tenderers may submit tenders for the individual lots and / or for various (or even all) lots, in the latter case specifying the proposed conditions, which must be better than those proposed for each individual lot. Here, the invitation or the program of the procedure must provide for the criteria on which the combination or aggregation hypothesis is based.

Finally, competitors may submit tenders for individual lots and / or for all lots (bundle). In this way, it is avoided that large companies seeking economies of scale deviate from batch-sharing procedures, opening up the possibility of winning all the lots (winner takes all).

\footnotetext{
${ }^{39}$ In this regard, see MIGUEL ASSIS RAIMUNDO's comment available at https://contratospublicos.net/2017/04/17/divisaoem-lotes-e-centralizacao-de-compras-duas-politicas-que-se-contradizem-e-anulam-ii/
} 


\section{The concept of economic operator (competitor) and the setting of limits on awarding by lots:}

As has been shown, the contracting authority may, in the invitation or the program of the procedure, provide for the combined or aggregated tendering of lots, on the basis of the wide margin of discretion granted in the legislation.

Contrary to the intended objective of the awarding by lots rule, however, this scenario can lead to disinterest by SMEs, since large companies may intuitively be considered as being the most suitable for the awarding of aggregated or combined lots.

It is accordingly understandable that the legislator has also made it possible for contracting authorities to limit the submission of tenders to a given number of lots or to set a maximum number of lots to be awarded per tenderer: a tool that will surely beused in thefuture (see Article 46-A of the PPCC).

In view of the limitation on the number of lots for which tenders may be submitted or the maximum number of lots to be awarded per tenderer - all of which is to be predetermined by the contracting authority - it may be expected that competitors, even if legally distinct but who maintain a common economic unit or have ties of interdependence, between them may submit several tenders for different lots or groups of lots in the same procedure. This with the intention of circumventing the limitations previously laid down by the contracting authority.

This problem has been examined by the scholarly writing, the Court of J ustice of the European Union and the national administrative courts, al beit in a related way.

In the 2009 Assitur $^{40}$ judgment, the issue arose in the case was whether two companies, between which there was a controlling interest, could legitimately submit tenders in the same procedure. The governing I talian law - which specifically regulated employment contracts - established an irrebuttable presumption that the controlled company's tender was known to the dominating company.

The law in question - the Legge Merloni (Law no.. 415, of 18 November 1998) - provided that tenders on all contracts offering an abnormally low price, itself identified by Community thresholds and by calculating the average of tender prices, would be compulsorily excluded. ${ }^{41}$ In practice, the system created by the Legge Merloni created incentives for competitors to submit multiple tenders, aiming to influence the estimate of the abnormally low price and thereby enhance their chances of success. 42

In response, the legislator considered that the two companies would not be able to submit proposals with thenecessary independence, seriousness and reliability, sincethey were associated

\footnotetext{
40 See Assitur judgment, proc C-538/07 of 19 May 2009, EU: C: 2009: 317. Commentary on the the Assitur judgment, see J OANA AZEREDO, A participação simultânea, num mesmo procedimento adjudicatório, de empresas que se encontram numa relação de domínio ou grupo e o princípio da concorrência, in Revista Electrónica de Direito - October 2016 - n.3, availableat https://www.cije.up.pt/download-file/1507.

${ }^{41}$ Explaining the facts underlying the Assitur judgement, see JOÃO AMARAL E ALMEIDA, A participação simultânea de sociedades em relação de domínio ou em relação de grupo em procedimentos de contratação pública, in Estudos em Homenagem a Mário Esteves de Oliveira, Almedina, Coimbra, 2017, pp. 28_37.

${ }^{42}$ Illustrating the Legge Merloni, see JOÃO AMARAL E ALMEIDA, A participação ..., p. 33 (n. 35).
} 
by a close communion of interests. The companies would ther efore beexcluded from the tendering procedure. $^{43}$

In the ensuing litigation, the Italian court referred a question to the CJEU as to whether the principle of "favor participationis" should overlap with a rulesuch as that laid down by I talian law, in order to safeguard the equal treatment of candidates and transparency of the procedure.

The CJ EU responded, based on the principle of competition in public procurement rather than competition law, by stating that the solution provided for by I talian law would considerably reduce competition at the Community level. The mere finding of a controlling relationship between the undertakings concerned, be it by virtue of a right of ownership or the number of voting rights they could exerciseat ordinary sharehol ders' meetings, was insufficient for the contracting authority to automatically exclude them from the awarding procedure. Rather, the contracting authority would have to first verify whether that controlling relationship had had a specific effect on the conduct of those companies in that procedure.

In the Assitur 44 judgment, the Luxembourg Court therefore held that European Union law is infringed when "(...) national legislation (...) provides for the automatic exclusion of participation in that procedure (...) both for a stable consortium and for the undertakings which aremembers of the consortium, where the latter have submitted proposals competing with those of the consortium under the procedure".

It should be noted that in the Assitur judgment it was not the application of competition law (whether national or European) that came into question, but only the examination of the possibility that associated companies could manipulate the calculation of the average prices proposed, thereby, disrupting the abnormally low price and as a result being automatically excluded under I talian law.

More recently, in the Lloyd's of London judgment of 8 February $2018^{45}$, the CJ EU examined the possibility of a Member State regulation allowing two competitors to be excluded from participating in the same tendering procedure on the grounds that their tenders were signed by the samegeneral representative.

Similarly to Assitur, the Lloyd's case turned on the Italian law regulating public procurement (Codice dei contratti pubblici relativi a lavori, servizi eforniture). Pursuant to Article 38(1)(m) of the Code, the proposers who are "in relation to another participant in the same award procedure, in a situation of domain under Article 2359 of theCivil Code or in any relationship, even if defacto, if the domain situation or the relationship implies that the tenders are attributable to a single decision-making center, would be precluded from participating in procurement procedures or conclude subcontracts relating to such procurement.

${ }^{43}$ Analyzing the economic effects produced by the joint participation, see GI AN L. ALBANO, GI ANCARLO SPAGNOLO and MATTEO ZANZA, Regulating J oint Bidding in Public Procurement, in J ournal of Competition Law \& Economics, Volume 5, Issue 2, 1, J une 2009, pp. 335-360.

${ }^{44}$ Se Assitur judgment, proc C-538/07, May 19, 2009, EU:C:2009:317.

${ }^{45}$ Se Lloyds of London judgment, proc. C-144717, February 8, 2018, ECLI:EU:C:2018:78. 
In the event, on 13 August 2015, Arpacal launched a public tender for an insurance contract to cover the risk associated with its civil obligations towards third parties and workers for the period from 2016 to 2018. The contract was to be awarded on the basis of the most economically advantageous offer.

Two L loyd's member unions - Arch and Tokio Marine Kiln - participated in this process, in which both offers were signed by the Lloyd's general representative for I taly.

Consequently, Arcapal excluded these two unions from the process due to an al leged infringement of Article 38(1)(m), on the grounds that the tenders were objectively attributable to a single decision-making centre as they had been submitted, formulated and signed by the same person,.

The CJEU considered that the automatic exclusion of candidates and tenderers who are in a control or associative situation with other competitors went beyond what is necessary to prevent concerted behaviour and to ensure application of the equal treatment principle and compliance with the obligation of transparency (seeparagraph 35). The Court concluded that "such automatic exclusion constitutes an inescapable presumption of reciprocal interference in the respective bids of companies linked by a control ling or associating relationship. It thus rules out the possibility of such candidates or tenderers demonstrating the independence of their tenders and is ther efore contrary to the Union's interest in ensuring the widest possible participation of competitors in a public tender."

Thus, in the Lloyd's of London judgment, the CJ EU conduded that the principles of transparency, equal treatment and non-discrimination arising from Articles 49 and 56 TFEU $^{46}$ must be interpreted as meaning they admit a Member State regulation not allowing the exdusion of two competitors from partici pating in the same public tender for insuranceservices on the solegrounds that their tenders were signed by the same general representative for that Member State. On the other hand the exclusion would be admissible if it were established on the basis of undisputed evidence that the proposals were not formulated independently. ${ }^{47} \mathrm{~A}$ similar decision was taken by the ECJ in the recent Specializuotas transportas judgement. ${ }^{48}$

Thus theAssitur case law and the more recent Lloyd's of London judgment both refer to situations in which the exclusion of bids from companies in the same group (i) was determined by national law in (ii) open pre-contractual procedures.

This article, however, addresses a separate question. In view of the limitation on the number of lots for which tenders may be submitted or the maximum number of lots to be awarded per

${ }^{46}$ On the relationship between these principles and public procurement law, see NUNO CUNHA RODRIGUES, A contratação pública ..., pp. 304-318.

${ }^{47}$ See Lloyd's of London judgment, proc C-144/17, 8 February 2018, EU:C:2018: 78.

48 See Specializuotas transportas judgement, C-531/16, 17 may 2018, ECLI:EU:C:2018:324. The court concluded that "the contracting authority, when it has evidence that calls into question the autonomous and independent character of the tenders submitted by certain tenderers, is obliged to verify, requesting, where appropriate, additional information from those tenderers, whether their offers are in fact autonomous and independent. If the offers prove not to be autonomous and independent, Artide 2 of Directive 2004/18 predudes the award of the contract tothetenderers having submitted those tenders." 
competitor - either limitation to be determined in advanceat the contracting authority's discretion - whether albeit legally distinct competitors that maintain an economic unit or interdependent links may submit bids for different lots or groups of lots in the same procedure.

Applying the reasoning of PEDRO GONÇALVES mutatis mutandis, al though according to formal legal logic, the underlying regime for groups of companies provided for in the Portuguese Commercial Companies Code, Article 54(2) does not directly regulate the situation at issue, it would follow that "(...) it cannot be said that a society dominated ("A") by another society, the dominant society ("B"), is itself a member of the grouping". 49

Since entities in a group relationship are not caught by the (2) of Artide 54 of the PPCC - legally different entities are therefore not considered a single competitor for the purposes of Article 59(7). Thus it could be concluded that there is no legal rule prohibiting the simultaneous participation of those entities in procedures where the maximum number of lots for which tenders may be submitted or the maximum number of lots to be awarded per tenderer have been limited.

To reiterate, however, the question is not whether entities within a group can be part of different groupings for the purposes of Article 54, $\mathrm{n}-2$ of the PPCC ${ }^{50}$, but rather whether, in those specific procedures where limits on awarding by lots by competitors were established, such companies should be regarded as a single competitor in the light of Article 53 of the PPCC.

In other words, the question is not whether the principle of prohibition of dual participation in a pre-contractual procedure under Article 59(7) of the PPCC has been respected. ${ }^{51}$

49 In the same vein, albeit not using the concept of company as in Competition Law, se PEDRO GONÇALVES, Direito dos Contratos Públicos, Almedina, Coimbra, 2018, p. 616. In a different sense, see MARIO ESTEVES DE OLIVEIRA, Agrupamentos de Entidades Adjudicantes e de Candidatos e Concorrentes em Procedimentos de Contratação Pública, in Estudos de Contratação Pública - II, Coimbra Editora, 2010, pp. 129 and ss. proposing an extensive interpretation of Article 54(2) of the PPCC.

${ }^{50}$ About the prohibition on competing participation in the same tendering procedure by a 'consorzio stabile' ('permanent consortium') and one of its member companies see case Serrantoni, C-376/08, 23 December, 2009, ECLI:EU:C:2009:808, conduding that "community law must be interpreted as preduding national legislation, which provides that, when a public contract is being awarded, with a value below the threshold laid down in Artide 7(c) of Directive 2004/18/EC but of certain oross-border interest, both a permanent consortium and its member companies are automatically exduded from participating in that procedure and face criminal sanctions where those companies have submitted tenders in competition with the consortium's tender in the context of the same procedure, even if the consortium's tender was not submitted on behalf and in the interests of those companies."

${ }^{51}$ As noted by PEDRO GONÇAL VES, Direito dos Contratos Públicos, Almedina, Coimbra, 2018, p. 615, “The prohibition of double participation is justified by the purpose of reducing the risk of information transfer or passing from one grouping to another (in the case of participation in more than one grouping) and, therefore, preventing and not promoting or facilitating practices that may distort competition rules. On the other hand, now from the perspective of public procurement's own values, what is sought is to prevent situations of false competition and non-genuine competition between economic operators which, after all, differ only on a formal level. (it is sometimes argued that it is advisable to give contrading authorities the power to define exceptions to the rul eon the prohibition of dual participation, in order to increasethe number of appl ications or tenders." 
Rather, the question at issue is whether, in the light of the notion applicable for the purposes of Competition Law, the possibility of setting limits on theaward of lots to competitors is an example in which the participation of related trading companies or, strictly speaking, different entities forming part of one undertaking, may make it difficult for third parties to participate and is accordingly not neutral. ${ }^{52}$

In response it is argued as follows.

In accordance with Article 53 of the PPCC, an economic operator (competitor according to the PPCC) is defined as "theentity, natural or legal person, who participates in any contract formation procedure by submitting a tender."

In Portugal, after initial confusion resulting from the erroneous application of the Assitur ${ }^{53}$ judgment, administrative jurisprudence has evolved to consider that different companies, despite presenting "the same corporate structure and the same managers", nevertheless "(...) are autonomous legal entities, having their own legal personality and, as such, it is considered that we are facing two competitors, each presenting its proposal. ${ }^{.54}$

This understanding was reiterated in 2016 in the TCASUL ruling ${ }^{55}$, which concluded that “(...) the Public Contracts Code (...) adhered to a definition of competitor based on the traditional concept of legal personal ity, determining that a competitor is a natural or legal person who submits a bid and therefore, such persons, not being grouped together for the purposes of a tendering procedure (in accordance with Article 54), are autonomous persons with autonomous tenders."

Consequently, as a preliminary rather that definitive conclusion, it may be assumed that even legally distinct competitors which maintain an economic unit or interdependent links may submit bids for different lots or groups of lots in the same procedure, al ways provided that the proposals were independently formulated (following the conclusive reasoning followed in the Lloyd's of London and the Specializuotas transportas judgments).

\footnotetext{
parties.

${ }^{53}$ See JOÃO AMARAL E ALMEIDA, A participação ..., pp. 46-47.

${ }^{54}$ See the TCASUL judgment, $\mathrm{n}^{\mathrm{o}}$ 12542/15 of 26.11.2015, available at www.dgsi.pt

${ }^{55}$ See the TCASUL judgment, $\mathrm{n}^{\circ} 13205 / 16$ of 26.11.2015, available at www.dgsi.pt
}

52 To this extent, the novelty that the 2014 Directives brought with regard to the division into lots and which have been incorporated into Artide 46(a) of the PPCC may now lead to a different conclusion from that stated by J OÃO AMARAL E ALMEIDA, A partici pação..., p. 51 in fine when heconsiders that the participation, in the same procedure, of two or more related companies is completely neutral with respect to competing third parties. The same reasoning can be applied to the change in the rules regarding the setting of prices or abnormally low bids, currently provided for in Article 71, which can now bedefined in the invitation to tender or call for proposals, "taking into account the percentage deviation from the average bid price to be admitted, or other criteria deemed appropriate" which may motivate the participation of several companies of the same group, in view of thechange in the average proposed prices and is therefore not neutral with respect to third 
In this case, some scholars considered it possible to invoke the (current) Article 70(2)(g) of the PPCC providing for the exclusion of tenders whose examination reveals strong evidence of acts, agreements, practices or information that could distort competition rules. ${ }^{56}$

However, we do not share this understanding.

The reason for exclusion under Article $70(2)(\mathrm{g})$ of the PPCC is to rule out proposals that violate competition law rules. Moreover, the aurrent wording corresponds to the wording of the original 2008 PPCC. $^{57}$

Exclusion in this case primarily concerns bid-rigging practices that often occur in the context of public procurement. $^{58}$

In our view, the cause of exdusion under Article 70(2)(g) will only occur in the event of infringements of competition law. This is why the legislator has provided, in Article 70(4) of the PPCC, that the exclusion of any proposals on the basis of paragraph $2(\mathrm{~g})$ and the existence of evidence of restrictive practices, even if they did not lead to the exclusion of the tender, should be notified to the Competition Authority. It cannot, therefore, apply to situations where the same undertaking seeks to use different legal entities (e.g. fictional companies) to try to win all tendered lots, in cases where the contracting authority has previously limited the maximum number of lots for which competitors may apply or may be awarded.

Indeed, informing the Competition Authority of a situation in which two companies in the same group submit different tenders for lots in the same procedure will not lead to the opening of any investigation. This is for the cardinal reason that in the light of Competition Law these two companies constitute a singlecompany, and there is accordingly no agreement between companies (bid_rigging). $^{59}$

56 In this regard, see J OÃO MOREIRA, Cartelização em Contratação Pública, in Estudos de Contratação Pública - III, Coimbra Editora, Coimbra, 2010, pp. 240 and 241 and, advocating that 'the application of Artide 70, no2 (g) of the PPCC should beextended" to "situations in which the samecompany will seek to use different legal entities (e.g. a" front company ") in an attempt to win all lots in a tendering procedure, thereby circumventing the limitation provided for in the parts of the procedure", see LUIS VERDE DE SOUSA, Algumas notas ..., p. 80.

57 The 2008 PPCC provided, in Article 70(3), that the exclusion of any proposals on the basis of (g) should be immediately notified to the Competition Authority (CA) and, as it stands in current wording, the CA must also be notified should there be evidence of restrictive competition practices. Furthermore, these are rules which underpin the provisions of the Directives. See recital 101 of the Classical Directiveand Article 57(d) of the Classical Directive.

${ }^{58}$ Analyzing other anti-competitive practices in public procurement (abuse of dominant position), se NUNO CUNHA RODRIGUES, A contratação pública ..., pp. $372-375$ and NUNO CUNHA RODRIGUES, Contratação Pública e concorrência: de mãos dadas ou de costas voltadas?, in Revista de Concorrência e Regulação, year VII, issue 32, October - December 2017, pp. 131 -146 (in particular pp. 139_142).

${ }^{59}$ In this sense, although in light of thegroup corporaterelations arising from theapplication of the Companies Code, see OÃO AMARAL E ALMEIDA, A participação simultânea de sociedades em relação de domínio ou em relação de grupo em procedimentos de contratação pública, in Estudos em Homenagem a Mário Esteves 
Given the impossibility of the contracting authority invoking that cause of exclusion, it may be asked whether therewill beother mechanisms for removing competitors who, sincethey maintain an economic unit or interdependent ties, submit bids in the same pre-contractual procedure with limits on lot numbers to be tendered for or awarded.

Because, in light of competition law, those same companies constitutea single company. ${ }^{60}$

Theanswer to this question will depend on the types of procedures concerned. Two basic types are as follows:

a) Open pre-contractual procedures:

In this case, competitors that are part of the same undertaking may submit different bids in the same pre-contractual procedure, in light of the principles of 'favor participationis', competition, transparency, equal treatment and non-discrimination. This follows from the Assitur and Lloyd's of London judgments ${ }^{61}$, which established that it is not sufficient to conclude that the competitors belong to the same business group. Rather it is necessary to verify whether, in the specific circumstances, this relationship had an effective influence on the content of the tenders submitted by each of the companies.

It should be noted that in these procedures, the principle of competition is fully assumed, which means that the exclusion of competitors is admissible only if it is found, on the basis of undisputed evidence, that the tenders werenot formulated independently.

b) Limited access pre-contractual procedures:

de Oliveira, Almedina, Coimbra, 2017, pp. 9 and following and RODRIGO ESTEVES DE OLIVEIRA, Empresas em Relação de Grupoe Contratação Pública, Revista de Contratos Públicos, n.2, 2011, pp. 89-109.

${ }^{60}$ Regarding this notion of company in Competition Law, seeNUNO CUNHA RODRI GUES, ibidem, pp. 381 386 and NUNO CUNHA RODRIGUES, A nulidade dos contratos públicos à luz do Direito da Concorrência, in Estudos de Contratação Pública, CEDIPRE, Coimbra, volume IV, 2012, pp. 181-230.

It should be noted that, for the purposes of competition law, the legal form taken by the company is irrelevant, requiring only consideration of the materially practiced economic activity, without imposing an analysis of its legal nature, which gives the concept a considerably broadened scope, conferring it a functional and broadened notion of company.

61 See also case Edilux, C-425/14, 22 october 2015, ECLI:EU:C:2015:721, conduding that a contracting authority may provide that a candidate or tenderer be automatically exduded from a tendering procedure relating to a public contract for not having lodged, with its tender, a written acceptance of the commitments and declarations contained in a legality protocol, the purpose of which is to prevent organised crime from infiltrating the public procurement sector.

Still, the ECJ recognizes that "however, inasmuch as that protocol contains declarations that the candidate or tenderer is not in a relationship of control or of association with other candidates or tenderers, has not concluded and will not conclude any agreement with other participants in the tendering procedure and will not subcontract any type of tasks to other undertakings participating in that procedure, the lack of such declarations is not to lead to the automatic exclusion of the candidate or tenderer from that procedure." 
In these procedures, the limitation is imposed ope legis (e.g. in public tender by prior qualification $)^{62}$ or by the contracting authority (e.g. in the invitation or program of the procedure), and aims to ensure that competitors in the procedure enjoy a certain level playing field with one another regarding their bidding capacity. ${ }^{63}$

In certain cases, more rigorous efforts are also being made to avoid the unfolding of thecorporate or business personality that would allow multiple proposals to be submitted.

The principle of competition is therefore preconditioned, in that it is not intended in such cases to attract as many opponents as possible but only those who have certain characteristics.

In this context, and in view of the nature of the pre-contractual limited access procedures, it will be permissi ble for the contracting authority to be able to limit, ex ante - in the invitation to tender or in the program of the procedure - the nature of the competitors who may apply to the procedure.64

Consequently, in light of the notion laid down in Competition Law, for cases where competitors in the same company (undertaking for competition law purposes) submit different bids in procedures where the contracting authority has restricted the maximum number of lots for which tenders may be submitted or which may be awarded per competitor, three solutions are proposed.

First, in light of the notion applied by competition law (see Article 132(4) of the PPCC), the contracting authority may, a priori, establish in the call or in the program of the pre-contractual limited access procedure, a ban on the participation of more than one company or entities of any kind that are part of the same undertaking,. ${ }^{65}$

62 ThePPCC distinguishes the concept of candidate (in limited access pre-contractual procedures), applicable at the first phase, from the one of competitor, applicable to any economic operator that submits a proposal (after the first phase in a limited access pre-contractual procedure or in an open procedure). Se artide 52 of the PPCC which states: "Candidates - it is consider to be candidate any entity, whether natural or legal, which participates in the qualification phase of a restricted competition by prior qualification, a negotiating procedure, a competitive dialogue or an innovation partnership by submitting an application."

${ }^{63}$ Although not expressly referring to it, this seems to beJ OÃO AMARAL E ALMEIDA's understanding in A participação ..., p. 54 which lists three examples where this is possible. (i) restricted tendering procedures by prior qualification or negotiation; (ii) public procurement procedures with a phase for the negotiation of bids and (iii) framework agreements.

${ }^{64}$ As noted by J OSÉ DUARTE COIMBRA, A adjudicação ..., pp. 366 regarding prior limitation of the maximum number of lots to be awarded per competitor, this limitation "(...) is naught but a way of anticipating (at the time of submission of tenders) the diversification effect of potential contractors that underlies thewhol elot-award schemeand, in particular, the very rule of Article46(4)(a) itself. If theaim here is to avoid concentrating on one operator all the benefits of awarding all or most of the lots, it is not difficult to understand that the most immediate way to avoid such concentration is to limit the procedural participation space of each competitor when submitting his bids to the various lots."

${ }^{65}$ See Article 132(4) of the PPCC: "4 - The tender program may also contain any specific rules on the public procurement procedure which the contracting authority considers appropriate, provided that they do not prevent, restrict or distort competition." 
In such a case, the contracting authority, using the procedural self_regulatory power provided for in Artide 132(4) of the PPCC, must forbid the participation of bidders of the same undertaking in the parts of the pre-contractual limited access procedure, in accordance with the notion provided for in Article 3 of the Portuguese Competition Act.

It should benoted that the notion of 'the undertaking' provided for in the Portuguese Competition Act does not only cover companies of the same group. It is also a question of all the companies which, although legally distinct, constitute an economic unit or maintain interdependent links, e.g. natural persons whohold shares in legal persons or even irregularly incorporated companies. ${ }^{66}$

The proposed scenario can be achieved, not only in pre-contractual limited access procedures where a limitation on departure or arrival is foreseen in the award by lots, but also in all procedures for restricted access to a qualified number of participants, in order to ensure the effectiveness of the competition principle in limited access procedures. ${ }^{67}$

The solution advocated does not conflict with the CJ EU case-law cited above, where the exclusion of proposals submitted by companies which were part of the same group (i) was determined by national law (ii) in open pre-contractual procedures.

As the present author understands, the hypothesis that arises allows us, to exclude competitors that are part of the same undertaking, in light of the concept provided for in Article 3(2) of Law no. $.19 / 2012$ of 8 May (Portuguese Competition Act), which may be determined by the contracting authority (i) previously in theinvitation or program of the procedure, and (ii) in limited access precontractual procedures. ${ }^{68}$

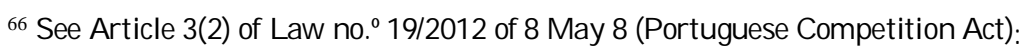

2 - A group of companies is considered to bea single company where, al though legally distinct, they constitute an economic unit or maintain interdependent links arising, in particular, from: (a) A majority interest in capital; (b) The holding of more than half of the votes attributed by the holding of shares; (c) The possibility of appointing more than half of the members of the management or supervisory board; d) The power to manage their respective businesses.

67 See PEDRO COSTA GONÇALVES, Direito dos Contratos Públicos, Almedina, Coimbra, 2018, p. 617: “In such cases, the prohibition has the legitimate purposes of, on the one hand, avoiding undermining genuine competition between different competitors and, on the other hand, deterring economic operators from the temptation of splitting into fronts with the ai m of occupying the seats available in the procedure" See also RODRIGO ESTEVES DE OLIVEIRA, Restrições à participação em procedi mento de contratação pública, in Revista deDireito Público e Regulação, no1, p. 34, available at http://www.fd.uc.pt/cedipre/

68 The question still arises as to whether the exdusion will cover all bids submitted by competitors that are part of the same undertaking, or whether one of the bids may be approved while all remaining bids are excluded.

It is understood that, because a single competitor - identified with a single company - is concerned, the contracting authority should exdudeall tenders that have been submitted by all competitors in the company. In this particular scenario, the plea under Article 146, no2 (i) of the PPCC could be applied, provided that the same competitor - in line with the notion provided for in the program of the procedure - submitted two (or more) proposals for each lot, breaching Artide 59(7) of the PPCC. 
Secondly, as suggested above, it may also be the case that the contracting authority has not a priori defined the prohibition on the submission of tenders to entities forming part of the same undertaking, in accordance with the notion provided for in Competition Law.

In that case, in accordance with the Assitur case-law, the contracting authority may assess the facts in order to determine whether the relationship between the two competitors had a concrete influence on the content of their tenders, sufficient to exclude those companies from the proceeding $^{69}$ or to resort to the theory of lifting the corporate veil or disregard of legal entity. ${ }^{70}{ }_{-}{ }^{71}$

These assumptions may be considered in open or limited access pre-contractual procedures.

The use of the theory of lifting the corporate veil or disregard of legal entity presupposes the practice of abuse of rights by a single company (al beit translated into the submission of different proposals) which fictionalizes the existence of several proposals by several competitors.

However, the concrete action of the theory of disregard of the legal entity of societies still suffers from a certain lack of theoretical rigour, because it relies not on concrete legal norms, but rather on principles such as good faith and abuse of law, related to the instrumentalisation of that entity. Furthermore, it is in fact controversial, since there are no entirely convergent understandings as to the formulation of the respective requirements. ${ }^{72}$

Third, in cases where, in line with the 2017 PPCC review, the abnormally low price is determined in the tendering program by setting a percentage deviation from the average bid - somewhat similar to the facts underlying the Assitur judgment - then the bids submitted by competitors which, in concert and even though being part of the same economic group, aim to distort the average bid price and in turn influence the value of the abnormally low bid - may be excluded not only where a rule to that effect is laid down in the tender program ${ }^{73}$, but also in light of Article 70(1)(c) of the PPCC. This is because since it is impossible to evaluate bids due to the form of presentation of any of the respective attributes - the proposed value - which, having been previously fixed or combined with other competitors (even within thesameeconomic group) cannot be objectively evaluated. In the latter case it should be noted that we are not within the scope of Competition Law, but only within the scope of Public Procurement Law, which is why we do not consider that thesimultaneous application of the provisions in Article 70(2)(g) of thePPCC is valid.

\footnotetext{
${ }^{69}$ See the Assitur judgment, cit., paragraph 32.

${ }^{70}$ Regarding the application of this theory to Administrative Law, see J OÃO AMARAL E ALMEIDA, Os organismos de direito público e o respectivo regime de contratação: um caso de levantamento de véu, in Estudos em homenagem ao Professor Doutor Marcello Caetano, FDL, Lisboa, Coimbra Editora, 2006, pp. 633656.

${ }^{71}$ Considering that in such cases, the exclusion of tenders submitted is based on the provisions of Article 146(2)(i) of the PPCC, provided that one competitor has submitted two tenders to each lot in breach of Artide 59(7) of the PPCC, see LUÍS VERDE DE SOUSA, Algumas notas ..., p. 80.

72 Regarding this theory, see, more recently, MARIA DE FÁTIMA RIBEIRO, A desconsideração da personalidadejurídica: as realidades brasileira eportuguesa, Direito das Soci edades em Revista, March 2016, Year 8, Vol. 15, pp. 29-57.

${ }^{73}$ As stated by J OÃO AMARAL E ALMEIDA, A participação ..., p. 57.
} 
In summary, this paper argues that in view of the new possibilities offered by the 2014 Directives and the revised PPCC on awarding by lots, including the possi bility for contracting authorities to limit the maximum number of lots for which each tenderer may apply and / or the maximum number of lots to be awarded per tenderer, it would be prudent for contracting entities, using the power of procedural self-regulation provided for in Article 132(4) PPCC, to prohibit the participation of competitors in the same undertaking. Further, in light of theconcept provided for in Article 3(2) of Law 19/2012 of 8 May, such prohibition should be provided for (i) in advance of the call or program of the procedure and (ii) in limited access pre-contractual procedures.

In other cases, i.e. open pre-contractual procedures where limits are set on the maximum number of lots for which tenders may be submitted or the maximum number of lots to be awarded per tenderer, the contracting authority may use the provisions of Article 70(1)(c) PPCC or the theory of lifting the corporate veil or disregard of legal entity in order to exclude tenders submitted even by companies of the same group in cases where, in accordance with the Assitur case-law, it is determined that " (...) the relationship of control at issue influenced the respective content of the tenders submitted (...) A finding of such influence, in any form, is sufficient for those undertakings to be excluded from the procedure in question."174

${ }^{74}$ Se Assitur judgment, cit., paragraph 32. 